DOI https://doi.org/10.36059/978-966-397-242-8-10

\author{
Шелепкова I. М., \\ старший викладач кафедри українознавства \\ і мовної підготовки іноземних громадян \\ Харківського національного економічного університету \\ імені Семена Кузнеця, \\ м. Харків \\ ORCID: https://orcid.org/0000-0001-9431-4868
}

\title{
ВІД ТЕРМІНА ДО ЕКОНОМІЧНОЇ ТЕРМІНОЛОГІЇ СУЧАСНОЇ УКРАЇНСЬКОЇ МОВИ
}

Анотація. Інтерес до терміна та економічної термінології став однією з прикмет сучасної дійсності. Про це, зокрема, свідчить той факт, що економічна тематика посідає важливе місце не тільки під час ділової комунікації, але і в повсякденному житті пересічної людини.

Слід зазначити, що економічні проблеми розглядаються $i$ аналізуються не тільки у виданнях, розрахованих на фахівців, але і у виданнях, орієнтованих на масового читача, що і спричинило широке використання економічної термінології поза професійної сфери. Отже, можна говорити про процес актуалізації економічної термінології в сучасній українській мові, а тому метою дослідження $\epsilon$ системний аспект економічної термінології із більш детальним аналізом закономірностей формування та шляхів і способів розвитку.

У зв'язку з означеним можна визначити й основну проблематику такого дослідження: установлення основних чинників, що сприяють змінам у термінології; з'ясування рівнів, на яких відбуваються найпомітніші зміни (семантичні, словотвірні, стилістичні, морфологічні тощо), а також дослідження основних шляхів становлення економічної термінології і входження їі до наявних систем тощо.

Вибір теми даного дослідження також є виправданим, оскільки глибоке дослідження економічної термінології дозволить провести роботу із уніфікації даної термінології. I як результат даної діяльності - дослідження процесів, що відбуваються в сучасній українській мові, а саме: процес активізації вживання іншомовних слів та запозичень, коли терміни набувають нового значення, розширення, звуження чи переосмислення значення; висвітлення питань формування української економічної термінології; з'ясування шляхів 
появи економічних термінів у термінологічній системі; визначення фонду економічної термінології і їі місия у словниковому складі.

\section{Вступ}

Вивчення проблем термінології, визначення її місця у структурі мови $€$ одним із актуальних завдань сучасної науки. Термінологія кожної окремої галузі засвідчує її досягнення на певному етапі історії народу і відображає перспективи подальшого розвитку.

Необхідність подальшого детального вивчення термінології української мови зумовлено, з одного боку, активним розвитком української термінології, що в повному обсязі ще не досліджено, а 3 іншого - потребою багатоаспектного вивчення всіх складників системи української мови, виявлення особливостей їх структури і функціонування, закономірностей їх взаємозв'язків.

Серед пріоритетних проблем сучасної української лінгвістики вбачається проблема економічної термінології. Сьогодні з'являються численні актуальні видання з економіки, менеджменту і маркетингу, лізингу i консалтингу, бухобліку i аудиту. Економічні терміни зазвучали в усній мові на радіо і телебаченні. Більшість ключових економічних термінів опинилися «на слуху» біля значної частини суспільства. У цих умовах не могло не виникнути підвищеної уваги до того, що активно формується економічною терміносистемою, що обумовлює, як нам здається, актуальність вибраної теми.

Мета роботи - досліджувати системні зв'язки в даній термінологічній сфері, представити економічну лексику у впорядкованому вигляді, виявити закономірності формування та шляхи і способи розвитку економічної термінології, визначити особливості системної організації економічних термінів.

Для досягнення поставленої мети необхідно вирішити наступні завдання:

1) розглянути діахронічний аспект формування економічної термінології;

2) описати словотворення в процесі формування української економічної термінології;

3) виявити й проаналізувати шляхи і способи формування економічної термінології на сучасному етапі;

4) дати структурно-семантичну характеристику даної терміносистеми;

5) виявити і дослідити сучасну найбільш уживану економічну термінологію; 
6) показати активні процеси в лексиці і словотворенні економічних термінів;

7) описати сфери функціонування економічної термінології.

На наш погляд, наукова новизна полягає в спробі комплексного аналізу даної групи термінологічної лексики, у тому обсязі і наповненні, який виявлений нами. Терміни, що аналізуються в роботі, взяті із сучасних видань словниково-довідкового характеру, а також засоби масової інформації.

\section{1. Історичні умови розвитку економічної термінології}

Термінологія як спеціальна галузь знання привертає значну увагу дослідників. Це пояснюється міжнародним характером сучасних наукових знань, що викликані процесами інтеграції і, як наслідок, прагненням до уніфікації термінів, подолання мовних перешкод у різних сферах соціально-економічної діяльності.

У процесі переходу до ринкових засад функціонування економіки в нашому лексиконі з'являється все більше нових, незвичних слів. Деякі ж відомі терміни, що часто вживаються, набувають нового значення. На початку 90-х років XX ст. українська мова набуває державного статусу - у зв'язку з чим виникає нагальна потреба подальшого розвитку власне української термінології.

Термінологія $є$ важливою частиною лексики літературної мови. У сучасному мовознавстві значно посилився інтерес до вивчення питань термінологічної науки, насамперед до становлення i формування окремих терміносистем, особливостей функціонування термінів у літературній мові, їх стандартизація.

Галузева термінологія виникає переважно на основі живої народної мови, використовуючи їі словотворчі можливості. Зокрема, особливості формування українських галузевих терміносистем зумовлюються структурно-граматичною специфікою національної мови. Водночас термінотворення породжує свої специфічні мовні моделі, що, проникаючи у загальнолітературну лексику, розширюють ї̈ словотвірний потенціал.

Необхідність детального вивчення української термінолексики зумовлюється тим, що, по-перше, сучасна термінологія є ще не досить глибоко досліджена, по-друге, існує потреба багатоаспектного аналізу всіх складників лексичної системи української мови, дослідження особливостей їх структури, взаємозв'язків і функціонування. 
В українських писемних пам'ятках XIV - XV ст. відбито значну кількість спеціальних понять сфери економіки. Фіксуються, зокрема, такі лексичні одиниці: вага (прилад для зважування, право стягати податок від зважування товару); встягати (вимагати сплати, притягати до відповідальності, переслідувати судом); выраховувати (віддати готівкою); личба (рахунок, фінансовий звіт, грошовий курс, сума, кількість); мито; мытник; набыте (набуте, придбане, куплене за гроші); ринокъ (торгова площа, ринок); складъ (місце зберігання товару); скупити (перекупити раніше придбане); товаръ (предмет купівлі-продажу, худоба, майно); тръгъ (місце, де відбувається торг, торгівля, угода про купівлю-продаж, товар, крам); цина (грошова вартість товару) [17].

Привертають увагу назви з виразною спеціалізацією. Так, наприклад, слово отмънити фіксується із значенням «відшкодувати, компенсувати».

Приход - у пам'ятках часто зустрічається із значенням «прибуток, доход, приход», тобто набуває значення «прибуток».

Із такою же спеціалізацією виступають й інші слова, наприклад: сужитокъ (прибуток, приріст); пожиток (користь, вигода, зиск).

Названі лексеми становлять ядро формованої протягом наступних століть спеціальної економічної лексики. Значення і функціонування частини з них зберігається протягом тривалого часу, інших - розширюється в подальшому шляхом утворення лексичних гнізд, коли навколо одного кореня групується ціла низка слів. Наприклад: продавати, продажа, проданіє (суч. продаж), проданъ; продавещь; торговець, торговський, торговля, торговати (суч. торговець) [17].

Досліджуючи в діахронічному аспекті спеціальну лексику на позначення ринкових відносин, переконуємося, що така лексика представлена головним чином у записах текстів виробничого й торговельного змісту.

Щодо ділової сфери, то торговельна лексика закріплюється у судових актах, супліках-скаргах, купчих і дарчих записах, духівницях, описах і реєстрах майна тощо, а також у приватних листах.

Виробнича лексика була пов'язана з живим мовленням і сприяла збагаченню словникового складу: «виробнича лексика, поряд 3 успадкованими словами, що характеризують людську працю взагалі, її основний поділ тощо, поповнювалася в староукраїнський період, особливо в XVI - XVIII ст., численними новими словами. Це було викликане інтенсивним розвитком і диференціацією різних 
видів робіт, виникненням нових професій, особливо міських, ускладненням майнових стосунків. Лексика виробничої сфери, активно вживана, переважно конкретна, мала, за деякими винятками, живомовний характер» [15, с. 72].

Таким чином, виробничі і торговельні терміни у значній кількості органічно входять до складу спеціальної лексики.

Спеціальні поняття на позначення ринкових відносин (на цьому діахронічному зрізі переважно торгівлі) постають у вигляді окремих слів, функція яких подвійна, тобто загальновживана і спеціальна.

Серед загальновживаних слів, що активно входять до фахового словника, здебільшого виділяються слова, широко відомі в практичній діяльності людини. Однак, як вже зазначалося, виробнича лексика краще, ніж терміни, зберігає побутову виразність: вимелокъ (оплата за помел зерна); кишковарка (торговка, що продає на базарі харчі); купилище (місце торгівлі); купцювати (вести торгівлю, бути купцем); перепродуха (дрібна торговка, яка продає на торгу їстівне).

Досліджуючи особливості термінів, що утворилися за рахунок переосмислення загальнонародних слів, відомих ще 3 періоду Київської Русі, вчені відзначають, що і в сучасній українській мові відповідні слова можуть уживатися як у термінологічному, так і в не термінологічному значенні.

Це такі, наприклад, терміни: гроші, купівля, продаж, ринок, товар, ціна.

Так, первісне значення східнослов'янського терміна товар рогата худоба. Шляхом навантаження цього слова новим лексичним значенням утворився його омонім: товар (для позначення різних предметів, що є об'єктами купівлі-продажу); товар (матеріальний виріб, що пропонується на ринку 3 метою його придбання, використання або споживання).

При утворенні терміна товар на основі відповідного загальновживаного слова як показника предметів купівлі-продажу конкретне значення цього слова поступилося перед вищим ступенем узагальнення, тобто термінологічне значення слова товар є одним із його лексико-семантичних варіантів, а тотожність даного слова при утворенні відповідного терміна не порушується.

Відомі сучасні терміни торгівлі гроші, ринок, сума, торгівля, як і розглянутий вище термін товар, перш ніж набути термінологічного значення, спиралися на загальновживане значення слова, тому маємо справу з утворенням нового лексико-семантичного варіанта. 
Відомо, що одним із широко розповсюджених шляхів утворення термінів $є$ утворення семантичним способом, суть якого полягає в тому, що змінюються значення слів, які вже існують у мові [11, с. 37 - 61].

Українська мова, як і в цілому слов'янські, розвивалась у контактах з іншими європейськими мовами.

Так, пам'ятки XIV - XV ст. фіксують слово крамъ на позначення роздрібної торгівлі; воно було запозичене 3 німецької мови, можливо, частково за польським посередництвом.

У тому разі, коли термін запозичується, він стає основою для творення похідних термінів засобами, властивими українському словотвору: крамъ $\rightarrow$ крамниця $\rightarrow$ крамар.

Коштъ - ціна; слово було запозичене через польське посередництво з німецької мови. Це запозичення стало основою для створення інших слів, які функціонують в українській мові: коштовний, кошторис, коштувати. Відповідна група слів органічно входить як у спеціальну лексику, так і в загальномовний словниковий фонд.

Беручи до уваги подане вище, можна погодитись із думкою В. Передрієнка, висловленою щодо економічної лексики XVIII ст. Дослідник пише, що саме економічний словник зазнав найбільш значних змін.

«Більш відкритий для книжних впливів, зокрема іншомовних, він, проте, перебував у постійному активному вжитку, в процесі якого виробився стійкий народно-розмовний лексичний шар» [15, с. 74].

У цьому шарі, активно чи пасивно засвоєному, автор виділяє назви, які характеризують майновий стан, економічні, торговельні та ділові стосунки: взялъ билъ в за(с)таву; дает(ъ) что на боргъ; далъ в позику.

Поява запозичених слів, очевидно, сприяла роботі над словниками, у яких простежуються перші спроби дати тлумачення терміна.

У словнику В. Доманицького [9] знаходимо тлумачення до таких номінацій досліджуваної сфери: аванс, банкир, відсоток, дебет, імпорт, квота, патент.

Лексичні одиниці імпорт, реклама, зокрема, фіксуються із такими значеннями: імпорт (так само, як імміграція, тільки прикладається не до людей, що виселяються, а до краму чи товару, що ввозять: експорт - що вивозять, імпорт - що ввозять); реклама (оповістка про щось по газетах та журналах, в якій вихвалюється те, про що оповіщається). 
Такі тлумачення могли стати основою для подальшого наукового визначення терміна.

Зважаючи на викладене вище, запозичення зумовлюються певними історичними причинами і характеризуються сферою вживання. Несприятливі політичні обставини в Україні ставали перепоною до вільного розвитку національної спеціальної лексики, основна частина українського народу стояла осторонь від усякого прогресивного руху в процесі ведення ринкового механізму господарювання. Торгівля з часом «русифікувалася».

Наявність російських слів у мові «торговців» Г. К. Данилов пояснює тим, що «торговцям» за родом їхньої діяльності увесь час доводиться виходити за межі своєї місцевості: у місто купувати продукти на заводі; перевозити їх залізницею тощо, де переважає російська мова [7, с. 184]. Без сумніву, причини такого явища мають більш глибокий зміст.

Поняття української економіки не було сформоване аж до XX ст. Досліджуючи цю проблему в контексті наукової і громадської думки $\mathrm{XIX} \mathrm{-} \mathrm{XX} \mathrm{ст.,} \mathrm{О.} \mathrm{Оглоблин} \mathrm{справедливо} \mathrm{зазначає,} \mathrm{що} \mathrm{«поняття}$ української економики ще й поднесь не усталене ні в науковій літературі, ні в широких колах громадянства. Довгі століття свого історичного життя Україна перебувала під чужими економічними та політичними впливами, що, безумовно, відбилося й на українській економічній думці» [12, с. 165].

Отже, проблема створення української наукової термінології, зокрема економічного спрямування, чекала і в першій третині XX ст. на своє розв'язання.

Термінологічною працею на сучасному етапі займається дуже багато вчених у різних країнах світу: в Австрії (О. Вюстер), у Німеччині (Гофман), Англії (Сейнер), Америці (А. Вовк), Польші (Гайда, 3. Стобески), Латвії (Р. Грабіс), Росії (В. Даниленко) та інші.

Термінологи обирають і працюють над одним або декількома напрямами в термінології. Так, термінологи Англії працюють над проблемою термінології та інженерії, польські вчені створили міжнародний орган уніфікації термінологічних неологізмів. У Німеччині розглядають зв'язок терміна з мовою для спеціальних призначень, в Австрії у центрі уваги - логічні аспекти термінології та міжнародні стандарти.

У Росії існує кілька термінологічних центрів, розташованих у Москві, Нижньому-Новгороді, Пензі, Омську, Воронежі. Московський центр (В. Лейчик, В. Гриньов, А. Герд) займається 
термінологічною лексикою та стандартизацією, проникає в структуру наукового тексту. У Нижньому-Новгороді розглядається проблема терміна і слова (В.Нємченко, Ю. Кобрин), у Воронежі (Є. Анушкін) приділяється увага лінгвістичній статистиці.

Праці українських вчених розглядають загальну картину розвитку української термінолексики, пояснюють специфічні процеси, характерні для термінології окремих наук.

У сучасному українському термінознавстві $€$ дослідження, присвячені природничій термінології (Л. Симоненко), юридичній (О. Сербенська), суспільно-політичній (Т. Панько), математичній (А. Крейтор), фізичній В. Пілецький), радіотехнічній (І. Кочан), соціально-економічній (Т. Панько, А. Бурячок), сільськогосподарській (П. Гриценко, Б. Стасевський), географічній (П. Чучка), образотворчій (Б. Михайлишин), театральній (А. Костюк), спортивній (М. Паночко) та ін.

Технічну та виробничу термінологію української мови досліджували Л. Симоненко, А. Крижанівська. Чимало термінологічних систем залишилося ще поза увагою дослідників.

Над проблемою «Термін і загальновживане слово» працювали Н. Непийвода, Г. Мацюк.

Загальнонауковій термінології та їі особливостям присвячене монографічне дослідження А. Коваль. Питання структури і системної організації українських термінів розглядалося в колективній праці (А. Крижанівська, Т. Панько, Л. Симоненко та ін.) «Склад і структура термінологічної лексики української мови».

Загальний огляд термінологічної роботи в Україні знаходимо у бібліографічному покажчику, укладеному А.Лагутіною та М. Богуцькою, «Термінознавство на Україні».

У сучасному термінознавстві спостерігається відхід від традиційного розуміння терміна як канонізованої та несуперечливої мовної одиниці. Особлива увага приділяється розгляду таких його категорій, як поліфункціональність, динамізм, відкритість.

Тенденції і проблематика майбутніх українознавчих досліджень термінології визначаються у працях окремих авторів [«Деякі міркування про шляхи i манівці розвитку української наукової термінології» (Кочерга, 1994), «Теоретичні засади українського термінотворення» (Панько, 1992), «Про засади відродження та розвитку української науково-технічної мови» (Перхач, 1993), «Українська мова в себе вдома сьогодні й завтра» 
(Шевельов, 1986)], а також у збірниках [«Науково-технічний прогрес і проблеми термінології» (1980), «Проблеми української науковотехнічної термінології» $(1992,1993,1994)$, «Проблемы языков для специальных целей, научной и профессиональной коммуникации» (1992) та інших].

Отже, маємо на сьогодні спроби опису термінологічних систем різних галузей знань, де, зокрема, визначаються риси та особливості спеціальної лексики.

Економічна термінологія, що $є$ об'єктом нашого дослідження, пройшла довгий шлях розвитку, але процес творення понять у ній відзначався певною стихійністю. Такий перебіг подій зумовлювався низкою як лінгвістичних (розвиток мови, міжмовні процеси, зникнення певних понять - і відповідно перехід економічних термінів до розряду історизмів, архаїзмів, появи нових понять неологізмів), так і екстралінгвальних чинників (розвиток економіки, вплив терміносистеми мови тієї країни, 3 якою співпрацювала Україна - німецької мови на початку XX ст. або англійської на його кінець, перехід від однієї системи господарювання до іншої тощо).

Сучасна українська економічна термінологія почала формуватися ще в період Київської Русі з розвитком торговельних відносин, пройшовши шлях від понять ремесел до одиниць сучасних міжнародних економічних відносин.

Загальновідомо, що справжній розквіт української лексикографії розпочався у 20-30-ті pp. XX ст. Видані в цей період перекладні (російсько-українські) словники були першими в розбудові лексикографічної роботи в Україні.

На сьогодні словники ділової мови 20-30-х pp. $\epsilon$ раритетними. Пропонуємо їхній перелік (скорочений), спираючись на покажчик Віктора Кубайчука:

Буряк Володимир. Словарь русско-украинский. - Одесса, б/р. 397 с. (з Додатком 1 - Слова пропущені або невповні переложені, 2 - Канцелярійний словник); Левицький М. Як писати службові папери українською мовою. - Черкаси: Сіяч, 1917. - 27 с.; Падалка Л. Російсько-український діловодний словник. Педагогічне Бюро Полтавського Губ. Земства. Полтава, 1918, 3 + 106 с.; Лебідь Д. Українська мова. Російсько-український словник та зразки паперів українською мовою. - Чернігів, 1918. - 254 с.; Бузинний О., Щепотьєв B. Короткий російсько-український словник // Практичний підручник діловодства. - К.: Книгоспілка, 1924. С. 43 - 83.; Російсько-украӥнський словник банкового діловодства / За 
редагуванням B.I. Орловського та І.М. Шелудька. - К.: Вид. Київської філії Промбанку, 1925. - 61 с.; Практичний російсько-український словник ділової мови (конторської та рахівничої) / Склали Є.Зінкевич, Б. Михайлович, П.Скрипник і І.Степаненко, за ред. М. Гладкого і К. Туркала. - К.: Час, 1926; К.: Книгоспілка, 1926; К.: ДВУ, 1926. -134 с.; Осипів М. Російсько-український словник щонайпотрібніших у діловодстві слів (Практичний порадник). Харків-Полтава, 1926. - 83 с.; Словник ділової мови. Термінологія та фразеологія (Проєкт) / Дорошенко М., Станіславський М., Страшкевич В. - Х.-К.: Держвидав України, 1930. - 260 с.

Словники, видані у 20-30-pp. XX ст., певною мірою задовольняли нагальну потребу в питанні культури української мови. Вони відіграли значну роль у нормалізації сучасної української літературної мови, поширенні мовних норм та їх кодифікації, у піднесенні української мовної культури початку XX ст.

Лексикографічні праці періоду $50-60-\mathrm{x}$ років XX ст. сприяли уніфікації тогочасної термінології. Серед них слід виділити «Російсько-український словник соціально-економічної лексики» С. Воробйової та Т. Молодід. Оскільки українську мова на той час вживалася обмежено (в освітніх закладах та державних установах переважала мова російська), словник подає переклад іншомовних лексем без власне українських відповідників.

Починаючи 3 90-х років XX ст., українська термінографія переживає новий етап свого розвитку: видається ряд тлумачних та перекладних словників у різних галузях науки і техніки.

Однією з найбільш грунтовних праць у цей час $є$ виданий 1994 p. Комітетом наукової термінології та Інститутом мовознавства ім. 0.0. Потебні НАН України «Російсько-український словник наукової термінології. Суспільні науки».

Серед значної кількості галузевих економічних праць найбільш грунтовними перекладними словниками, що характеризуються чіткістю й унормованістю словникових статей, сприяють систематизації та стандартизації економічної термінології, правильному, свідомому використанню галузевих термінологічних одиниць, $\epsilon$ «Українсько-російський і російсько-український словник: Сфера ділового і професійного спілкування» Віктора Бріцина та Олександра Тараненка, що вийшов друком у Києві 2011 року.

Поряд 3 великою кількістю перекладних словників наприкінці $\mathrm{XX}$ - на початку XXI ст. було видано й низку тлумачних економічних словників, таких, наприклад, як «Економічний словник-довідник» 
за редакцією доктора економічних наук С. Мочерного (1995). Валерій Коломойцев створює «Універсальний словник економічних термінів: інвестування, конкуренція, менеджмент, маркетинг, підприємництво» (2000).

2002 року виходить друком четверте видання «Фінансового словника» Анатолія Загороднього, Геннадія Вознюка та Тамари Смовженко, що містить визначення й тлумачення понад 5000 понять і термінів, які охоплюють такі теми: фінансова система держави, місцеві фінанси, фінанси підприємств, фінансування і кредитування підприємницької діяльності, цінні папери і фондовий ринок тощо.

Найбільшим за обсягом охоплених термінів і за детальністю тлумачення понять $\epsilon$ цикл наукових праць «Економічна енциклопедія» у трьох томах (2000 - 2002) та «Економічний енциклопедичний словник» у двох томах (2005 - 2006). У виданнях максимально точно подано характеристику економічних категорій, понять, теорій та концепцій економічної науки.

Незважаючи на низку праць про економічну термінологію (в основному це дисертаційні роботи, присвячені таким питанням, як закономірності формування та сучасного розвитку термінології ринкових відносин (О. Покровська); характеристика структурносемантичних параметрів аналітичних номінацій економічної терміносистеми української мови (О.Чуєшкова); дослідження новітньої економічної термінолексики у плані комунікативностилістичного функціонування у текстах періодичних видань (Г. Чорновол) та ін.), сьогодні потребують свого дослідження такі аспекти у вивченні економічної термінології, як:

- висвітлення питань формування української економічної термінології;

- з'ясування шляхів появи економічних термінів у термінологічній системі;

- визначення фонду економічної термінології та їі місця у словниковому складі;

- розмежування економічного терміна і загальновживаного слова;

- диференціювання термінів за ступенем семантичної цілісності;

- дослідження й системний аналіз економічних термінів і простеження впливу на них таких процесів, як тяглість і зрушення. 


\section{2. Основні способи формування української економічної термінології}

\section{1. Словотворення як спосіб формування української економічної термінології}

Як відомо, твірна здатність основ термінів сприяє розширенню бази найменувань, а також спеціалізації самих термінів. Важливість принципів термінотворення набирає особливого значення, оскільки чіткість і прозорість словотвірних моделей прямо пов'язана як із внутрішньою формою, мотивованістю терміна, так і 3 конкретністю, виразністю його семантики.

Необхідно також ураховувати, що «вдалі терміни можуть сприяти розвитку науки, а невдалі - гальмують розвиток наукових знань» $[4$, с. 6].

Чільне місце в економічній терміносистемі посідає морфологічний спосіб творення термінів, що полягає у поєднанні афіксальних морфем із мотивованою основою слова. Морфологічному способові термінотворення економічних понять властиві загальні закономірності, характерні для української мови в цілому.

\section{2. Суфіксальній спосіб формування української економічної термінології}

Для досліджуваної технології поширеним є суфіксальний спосіб словотворення. Він полягає у тому, що шляхом приєднання переважно до іменних основ суфіксів утворюються терміни на позначення певних понять або явищ об’єктивної дійсності.

Зважаючи на те, що основну масу економічних термінів становлять іменники, зазначимо, що предметом нашого дослідження у даному випадку стали однослівні найменування. Терміни-іменники, утворені суфіксальним способом, поділяються на деривати, мотивовані основами іменників, дієслів i прикметників.

Значною продуктивністю при творенні економічних термінів, які означають абстрактні назви опредметненої дії, відзначаються словотвірні типи з суфіксами -анн(-я), -енн(-я), -інн(-я), рідше -к(a).

Як показує фактичний матеріал, у терміносистемі ринку назви абстрактної дії частіше виражаються віддієслівними іменниками, ніж дієсловами.

Процесуальність, яка $є$ в дієслові категоріальною ознакою, у віддієслівних іменниках виступає як лексичне значення. Самі 
суфікси, за допомогою яких утворюються віддієслівні іменники, мають чітке словотвірне значення.

Утворення словотвірного типу з суфіксом -анн(-я), -енн(-я), -інн(-я) представлені в таких номінаціях: авансування, акредитування, затоварювання, експортування, асигнування, імпортування, подорожчання, знецінювㅁня, компенсування, відшкодування депонувㅁня коливання, конвертування, перевезення, котирування, оподаткування сплачування оприбуткування, пропонування збереження, інвестування тезаврування, фрахтування тощо.

Як уже зазначалося, малопродуктивним при творенні української термінолексики ринку є словотвірний тип із суфіксом -к(a) у значенні опредметненої дії. Утворення цього типу представлені кількома термінами: покуп $\underline{a}$, затримㄸa, поставㄸa, упаков $\underline{\text { а. }}$.

У творенні економічних термінів значне місце належить поліфункціональному суфіксу -ик(-ік) з похідними -ник, -овик.

У сучасній українській мові суфікс -ик у відіменникових утвореннях не відзначається продуктивністю.

Тип дериватів із суфіксом -ник представлений у економічній термінології назвами осіб за характером і сферою їх діяльності:

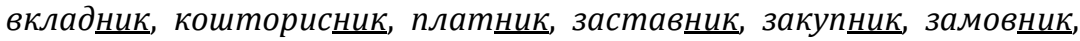

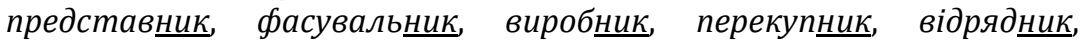
боржник, приватникта ін.

Похідний від -ник суфікс -льник приєднується до основ інфінітивів на $-a$, -ува (-юва). Головне словотвірне значення цього суфікса - особа як виконавець дії, названої дієсловом.

Так, деривати: позичальник, постачальник, приймальник, таксувальник страхувальник нормувальник комплектувальник мотивовані відповідно дієсловами: позичати, постачати, приймати, таксувати, страхувати, нормувати, комплектувати.

Незначну частину іменників утворено за допомогою словотвірного типу з суфіксом -овик. Утворення відбулося шляхом перерозкладу суфікса відносних прикметників -ов -ий $+u \kappa$, наприклад: оптовий оптовик; плановий - плановик; біржовий - біржовик; пайовий - пайовик; харчовий - харчовик; страховий - страховик.

Утворені номінації означають осіб як спеціалістів, що займаються тією чи іншою діяльністю, або як членів певного колективу. Необхідно також зазначити, що в дериватологічній системі сучасної української 
економічної термінології словотвірний тип на -овик не набув значного поширення і не позначився суттєвою активністю.

Для словотвірного типу з суфіксом -ств(o) та його аломорфа цтв(о) характерним $€$ утворення номінацій від мотивованого іменника-назви особи-діяча, а також абстрактних назв (утворені назви функціонують як у вузькогалузевій сфері, так і задовольняють потреби загальнонаукового вжитку): агент - агентство; підприємець - підприєм ство; комісіонер - комісіонерство; фактор факторство; банкрут - банкрутство та ін.

Малопродуктивним в економічній термінології $€$ словотвірний тип із суфіксом -ант (-янт) на позначення особи: спекулянт; контрактант; конкурсант; трасант; індосант.

На базі запозичених основ утворилися терміни з суфіксом -аж на означення кількості будь-чого, дії, збірник понять, наприклад: амбалㅆ; кулㄸ; куртаж.

Словотвірний тип із суфіксом -ер (-єp), -ар (-яp), -ор бере участь у творенні іменників на позначення професії, відношення до організації, характеру діяльності у сфері економіки, наприклад: дистриб'ютор; акціонер; аудитор; інвестор; комівояжер; ліцензіар; орендар; франчайзер; менеджер; інкасатор; дисконтер; імпортер, експортер, тендер та ін.

Значне місце в економічній термінології посідають номінації, що оформлюються за допомогою суфікса -ість. Виражені іменником, терміни з суфіксом -ість творяться від мотивованих якісних i відносних прикметників із суфіксами -н-, -ов-, -ив-, -ев-, -є8-, -ільн-, вони означають якість, властивість, процес, величину: ліквідність; вартість; ; економічність; ; прибутковість; оборотність;

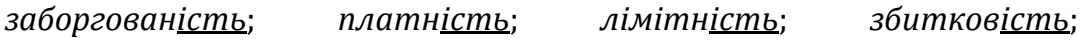
рентабельність; товарність тощо.

Менш продуктивними при творенні економічних термінів $\epsilon$ словотвірний тип із суфіксом -ець, терміни в окремих випадках мотивовані складними іменниками і позначають осіб: продавець, векселедавець, покупець, товарознавецьта ін.

Українська економічна термінологія містить значну частину термінів на означення дії безвідносно до часу, утворених за допомогою продуктивного в термінології суфікса -аці(-я), такі утворення мотивовані основами дієслів на -уват (-юват): приватизація; інфляція; конфіскація; інкасація; нотифікація; тарифікація; стагнація; реаліздція та ін. 
Нерідко зустрічаються і субстантиви із суфіксом -изм (-їзм), які визначають абстрактні якості. Суфікс -изм (-їзм) приєднується переважно до основ іншомовного походження: абсентеїзм; монополізм; монетариззм; фордизм тощо.

Проведений аналіз дозволив виявити специфічність словотвірних дериватів у процесі творення економічної термінології.

Досліджувані терміни дають підставу зробити висновок про те, що похідною основою переважно виступають іменники, меншою мірою дієслова, прикметники, роль форманта виконують суфікси.

Серед суфіксальних дериватів переважає категорія назв із опредметненою дією, назви осіб за відношенням до предмета або за характером діяльності у сфері економіки.

Суфіксальній спосіб словотворення становить собою найбільш розгалужену й активну частину словотвірної системи української економічної термінології, яка визначає її структурну однорідність.

\section{3. Префбіксальний та префіксально-суфіксальний способи формування украӥнської економічної термінології}

Творення нових номінацій сфери економіки характеризується як однобічним ускладненням основи (за допомогою тільки префікса), так і подвійною її мотивацією (за допомогою префікса і суфікса). Це і зумовило об'єднання аналізованого мовного матеріалу (префіксального і префіксально-суфіксального способів).

При утворенні економічних термінів використовують як власне українські префікси: без-, над-, понад-, під-, проти-, пів-, навпів-, так і префікси іншомовного походження: zinep-, екстра-, суб-, анти-, де- тощо.

Найбільшою продуктивністю відзначається префікс без-, що означає відсутність певної ознаки чи якості, мотивованої основою: безконтрольний; безпатентний; безплатний; безмитний; безкошторисний; беззвітний; безтарифний; безтоварний; беззбитковий тощо.

Префікси над-, понад- беруть участь у творенні як термінівіменників, так і термінів-прикметників сфери економіки: надподаток; понадлімітний; ㅎлмонополія; понадплановий; надприбуток; надкошторисний; надвартість тощо.

Творення термінів для позначення нових понять таким способом $€$ досить поширеним у сучасній ринковій термінології.

Значно рідше у творенні економічних термінів беруть участь іншомовні префікси гіпер-, екстра-, що також виражають найвищий 
ступінь виявлення кількісної та якісної ознаки, названої мотивуючою основою: әіперінфляція; екстраполяція та ін.

Незначна кількість номінацій утворилася за допомогою

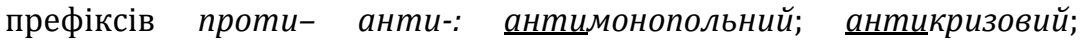
антиінфляційний; протиінфляційний;

Префікс де- вживається у номінаціях із значенням ліквідація, знищення: десегрегація; делімітація; деномінація; демонетизація та ін.

Таким чином, ми з'ясували морфемно-словотвірні та семантичні особливості економічних термінів у сучасній українській мові. Наведені вище спостереження свідчать про те, що для творення економічних термінів префіксальним та префіксальносуфіксальним способом використовуються ті ж самі засоби, що і для творення загальномовних слів.

Найактивнішим є суфіксальній і префіксальний чи префіксальносуфіксальний способи творення економічних термінів, значно менш продуктивним $\epsilon$ спосіб скорочення слів. Проведений аналіз дає можливість оцінити наявні терміни досліджуваної сфери і відібрати ті, що задовольняють виробленим вимогам.

Морфологічний спосіб утворення термінів ринку залишається одним із найбагатших джерел поповнення сучасної української економічної термінології.

\section{4. Синтаксичний спосіб формування української економічної термінології}

Економічна терміносистема відзначається досить високою продуктивністю творення нових термінів синтаксичним способом. Відомо, що словосполучення, які складають важливу частину термінологічного фонду будь-якої мови, становлять гостру проблему лінгвістичного термінознавства:

- не з'ясовано їх статус, межі, сутність, типи й властивості;

- не вироблено чіткі критерії розрізнення їх і вільних сполучень термінів;

- відсутня єдність способів уявлення словосполучень у термінологічних словниках і відбору їх у словники різних типів.

За своїм кількісним складом терміни-словосполуки посідають в економічній термінології одне з перших місць, треба відзначити, що ці деривати є характерними й для інших галузей знань.

Таке мовне явище В. Даниленко пояснює тим, що терміни словосполучення «здатні 3 найбільшою повнотою відобразити необхідні відмітні риси поняття, яке називається. Термінами- 
словосполученнями легше, ніж іншими словотворчими способами (афіксальними, наприклад), передати належність до класифікаційного ряду, грунтованого на родо-видовому співвідношенні понять» [5, с. 132].

Отже, цей тип дериватів відображає родо-видову ієрархію понять, дає можливість установити місце певного терміна в низці однорідних і виділити з цієї низки зі зазначенням його характерних особливостей: активи вільні; активи грошові; активи ліквідні; активи матеріальні; активи не матеріальні; активи поточні.

Терміни-словосполучення, що виражають цілісні поняття сфери економіки, мають різний ступінь смислової розкладності. 3 погляду семантики можна виділити два їх різновиди:

- номінації з частковою або втраченою мотивацією (такі терміни грунтуються на переносно-образному вживанні одного 3 його членів чи всього словосполучення): валютний кошик; зняття вершків; ножиці цін; втеча від грошей; доларовий голод; гарячі гроші; ведмежий ринок тощо;

- номінації, мотивація яких зрозуміла: асортимент продукцї; нецінова конкуренція; простоювання товару.

Терміни-словосполучення, як показує фактичний матеріал, утворюють переважно модель підрядної залежності компонентів узгодження та керування: стійка ціна; зниження ціни.

В економічній термінології частіше використовуються моделі, побудовані на узгодженні складових частин: гарантія надійна; заборгованість ліквідна; кредит дешевий; пропозиція комерційна; ревізія внутрішня; якість гарантована.

У наведених номінаціях означуване слово називає родове поняття, а означення дає видову характеристику.

Узгоджуване слово здебільшого прикметник: борг короткостроковий; відомість шахматна; інвестиція реальна; операція венчурна; продукція ліцензована.

Терміни-словосполучення, побудовані за моделлю керування, становлять здебільшого безприйменникові форми компонентів: страхування вантажу; викуп акцій; обслуговування населення; послуги комерційних банків; фінансування торгівлі.

У системі української економічної термінології спостерігається і сурядний зв'язок компонентів. Зокрема такий зв'язок виявляємо в термінах, виражених іменником у називному відмінку з узгодженою або неузгодженою прикладкою: соло-вексель; країна-кредитор; 
країна-боржник; банк-гарант; виставка-продаж; купівля-продаж; ноу-хау; холдинг-компанія; виставка-ярмарок.

Цей тип номінацій може утворювати і більш складну форму структурної організацій, компоненти у такому разі об'єднуються як сурядним, так і підрядним зв'язком: ноу-хау незапатентоване; ноухау технічне; купівля-продаж цінних паперів.

Серед економічних термінів-словосполучень виділяють такі структурні моделі:

- іменник + іменник (покриття витрат; стягнення податку);

- прикметник + іменник (нецінова конкуренція; інформативна реклама);

- іменник + прикметник + іменник (місткість товарного ринку; вибір маркетингових засобів);

- іменник + іменник + іменник (поліпшення якості товарів; закон підвищення потреб).

Зустрічаються також термінологічні сполучення, що становлять прийменникові форми компонентів: акцепт із застереженням; внесок до бюджету; конкуренція у сфері ліцензійної діяльності; реклама на сферу торгівлі.

За походженням компонентів двоскладові словосполучення можна поділити на групи, кожна з яких утворює певну модель:

- національне + національне слово (покриття попереднє; грошові нагромадження);

- національне + іншомовне слово (тривалість кредиту; фінансові показники);

- іншомовне + іншомовне слово (паблік рилейшнз; блю-чіп; соло-вексель; ноу-хау).

Фактичний матеріал показує, що в українській економічній термінології чимало багатокомпонентних термінів, які не можна назвати вдалими. Очевидно, це пов'язано із прагненням відтворити складну внутрішню форму закладеного у термінологічну номінацію наукового поняття: кредитування простого $i$ спеціального $i$ позичкового рахунку; норми використання готівки з виручки; податок за грошові перекази за кордон.

Сучасна економічна термінологія української літературної мови результат історичного розвитку української мови. У процесі еволюції терміносистеми змінювалися способи номінації спеціальних понять економічної семантичної сфери: від, переважно, лексикосемантичного способу творення термінологічних одиниць, продуктивного у староукраїнський період XIV - XVIII ст. (судові акти, супліки- 
скарги, купчі і дарчі записки, духівниці, описи і реєстр майна, приватне листування), до утворення складних термінів на сучасному етапі розвитку української мови, тобто термінологізації тією або іншою мірою піддається значна частина лексики офіційно-ділових текстів.

Справа не тільки в прагненні тих, що створюють ці тексти, до точності й адекватності позначень, але і в тому, що у розпорядженні того, хто складає діловий документ, вже $є$ набір вироблених засобів вираження, відхилення від яких було б непотрібним i невиправданим не тільки і не стільки тому, що воно призвело б до порушення стилістичної тональності тексту, але i у багатьох випадках тому, що заважало б «семантичній адаптації» того, що повідомляється, його співвідношенню з даним і відомим.

Уміння правильно скласти діловий документ, який буде бездоганний із граматичної точки зору i спрямований на якнайкраще мовне втілення основних стилістичних рис ділового мовлення, вирішить специфічні завдання комунікації. Тому при роботі з термінами необхідно звертати увагу на точність дефініції, що приводиться, і правильний вибір тієї або іншої одиниці при побудові тексту ділового документа.

\section{5. Економічні терміни у засобах масової комунікації}

У наші дні економічна термінологія вийшла далеко за межі сфери професійного спілкування. Ї̈̈ вживання актуалізується в широкому спектрі комунікативних ситуацій і відповідних до них типів і жанрів мови.

Чинником, що об'єднує всі різновиди економічної мови, є чинник теми, тобто це економіка у всіх їі іпостасях. Тема, фрагмент дійсності, що стоїть за текстом, і визначає наявність у нього економічної термінологї.

Інші параметри можуть варіюватися: форма мови (письмова / усна); тип спілкування (віч-на-віч / публічно, безпосередньо / опосередковано, офіційне / неофіційне); характер заповнення позицій той, що говорить / адресат (залежно від комунікації соціальної ролі, що реалізовується в акті, від кількісних показників - один / багато і якісного наповнення цих показників); комунікативні інтенції партнерів, багато в чому визначають характер мовного жанру (жанри інформативного, аналітичного, полемічного, спонукального характеру і ін.). Поєднання названих параметрів може давати різні типи текстів, в яких представлена економічна термінологія. 
Природно, центральною зоною функціонування економічної лексики є спеціальна мова (у писемній / усній формі).

У цьому випадку партнери комунікації виступають як носії однієї соціальної ролі (це мова професіоналів для професіоналів).

Заміщення позиції адресата «неспеціалістами» дає різні типи науково-популярної мови. Розмова на економічні теми в побутовому спілкуванні - типова прикмета часу. У подібних випадках партнери комунікації - неспеціалісти, «економісти мимоволі», в активний словниковий запас яких потрапляють економічні терміни (ваучер, приватизація, крупні купюри, курс долара тощо).

Неперсоніфікований масовий адресат характерний для засобів масової комунікації, при цьому одні видання (передачі) розраховані на фахівців, інші - на широкого читача (глядача, слухача).

Масового адресата мають і деякі жанри міської мови - вивіски, оголошення (купівля-продаж, найм, обмін, послуги і ін.), усна вулична реклама та ін.

Засоби масової інформації в даний час є основним інструментом впровадження економічної лексики і економічних знань. Велика частка економічної тематики на телебаченні чи в інтернеті - це інформаційний жанр: новини, економічні шоу чи покупка за замовленням рекламованого товару в інтернеті.

Інтернет-реклама активно входить у повсякденне життя, розходиться в цитатах. Нагадаємо лише деякі з них: «Нудуже смішні ціни!»; «Ми сидимо, а гроші йдуть!», «Це більше, ніж стипендія. Це краще, ніж стипендія. I це тільки початок».

Своєрідним ретранслятором реклами стає преса чи інтернетвидання. Репліки інтернет-реклами дають назви рубрикам. Проте основний масив рекламних оголошень становлять спеціалізовані письмові видання - журнали, газети, популярні газети рекламних оголошень.

У порівнянні 3 інтернет-рекламою, де значна частина рекламного простору відводиться «вихвалянню» товару і спонуканню до його придбання (зі стандартним набором аргументів), то реклама в газетах має суто інформативний характер.

Популяризація економічних знань стала однією 3 прикмет сучасної преси. Типові статті, присвячені новим типам економічних ситуацій і відносин, новим професіям тощо.

Засоби масової інформації стають не тільки популяризаторами економічних знань, вони намагаються впливати на читача, 
рекомендуючи моделі поведінки в новій економічній дійсності (куди вкласти кошти, кому довірити гроші і ін.).

Жанр рекомендацій і застережень $є$ одним із популярних.

Наприклад, характерні заголовки: "Якби путівку вибирав я...»; "Декілька рекомендацій професіонала»; "Як не стати жертвою шахрая» тощо.

\section{6. Набуття словом нового значення \\ (розширення, звуження, переосмислення) як спосіб бормування української економічної термінології}

Поява чогось нового в житті суспільства, точно так, як і пізнання нових предметів і явищ, викликає необхідність номінації, що спричиняє за собою утворення в мові нових слів і виразів або появу нових значень. Але в той же час розвиток лексики визначається внутрішньомовними чинниками, пов'язаними 3 системним характером мови.

Так основними способами створення економічних термінів залишилися в мові ті, що були раніше: словотворення, словоскладання, утворення складених найменувань, запозичення. Усі ці способи активно використовуються при позначенні нових реалій.

Істотними, що впливають на утворення лексичних неологізмів, стають, зокрема, міжнародні економічні зв'язки, що все більше розширюються, сприяючи збільшенню фонду лексичної системи.

Хоча економічні реформи не спричинають створення принципово нової мови, проте значно збільшують термінологічний фонд, який, у свою чергу, збагачує загальнолітературний словник шляхом детермінологізації, де важливою умовою для життєздатності $€$ системні якості, що сприяють виробленню доцільних і зручних засобів вираження.

Представлені процеси в сучасній лексиці ілюструють активність соціальних чинників в економічній термінології - i в сфері семантики, і в стилістичних зрушеннях, і в активізації іншомовних запозичень. Сучасна лексика відображає час становлення нової економіки. У мові зафіксовано поверненням старих слів в активний словник ужитку - приватизація; комерція: «Приватизація - процес передачі об'єктів державної або муніципальної власності $у$ колективну або особисту власність.

Приватизація державного житлового фонду - відчуження квартир (будинків) та належних до них господарських споруд $i$ 
приміщень з державного фонду на користь громадян» [2, с. 1110]. «Комерція - торгівля й пов'язані з нею справи» [2, с. 559].

Наявна актуалізація економічних термінів: прибуток; депозит. «Прибуток. Абсолютний (чистий) прибуток - прибуток, що дорівнює доходу, який отримав продавець від усіх товарів за вирахуванням витрат, сплати податків.

Базовий прибуток - очікуваний прибуток звітного року, що використовується для розрахунку базової рентабельності.

Балансовий прибуток - загальна сума прибутку підприємства за всіма видами виробничої діяльності, відображена у його балансі.

Біржовий прибуток - дохід від торгівлі цінними паперами на фондовій біржі та масовими товарами на товарній біржі.

Емісійний прибуток - різниця між ринковою вартістю цінних паперів, за якою їх реалізують, та емісійною ціною, за якою їх випущено.

Залишковий прибуток - частина прибутку, яка залишається в розпорядженні підприємства після виплати обов'язкових платежів - відрахувань до державного бюджету, процентів за банківські кредити і т. ін.

Чистий прибуток - те саме, що абсолютний прибуток» [2, с. 1110]

«Депозит. Гарантійний депозит - кошти, що їх банк-кредитор із метою захисту від ризику переводить на депозитний рахунок.

Депозит до запитання - кошти, що їх власник банківського депозиту може зняти без попереднього повідомлення банку.

Депозит-овернайт - депозит банку на термін не більще одного дня» [2, с. 285].

Розгляд специфіки словотворчих процесів економічних термінів виявив помітну інтенсивність їх протікання. Не дивлячись на стабільність і традиційність основних способів словотворення, результати словотворчих процесів за кількістю отриманих економічних новоутворень $\epsilon$ значними. Особливо активним $\epsilon$ утворення абстрактних іменників, диференційованих за родом діяльності: ріелтер, аудитор, менеджер.

Активними як база словотворення є слова, пов'язані з розвитком ринкових стосунків: бізнес, банк, підприємець.

Високу продуктивність виявляють словотворчі елементи іншомовного походження.

Вживання економічної термінології актуалізується в широкому спектрі комутативних ситуацій і жанрах мови. Центральна зона функціонування економічній лексиці є спеціальна мова в письмовій 
і усній формі. Причому економічні терміни вживають і економісти, i неспеціалісти, в активний запас яких вони потрапляють.

Зміни у сфері економіки призвели до зміни тлумачення слів у цій сфері. Дуже часто це пов'язано зі зникненням в них деякого визначення. Так, в словарній статті, присвяченій слову «банк», опущена частина тлумачення, пов'язана 3 коментарем про роль банків при капіталізмі і при соціалізмі; у словарній статті до слова «біржа» прибрана частина «в капіталістичних країнах»: точніше сформульовано слово «брокер».

Так, сьогодні ми можемо читати таке тлумачення слова «банк» у сучасних словниках:

«Банк - кредитно-фінансова установа, яка зосереджує кошти $i$ капіталовкладення, надає кредити, здійснює грошові розрахунки між підприємствами або приватними особами, регулює грошовий обіг у країні, в тому числі випуск (емісію) нових грошей.

Акціонерний банк - банк, статутний капітал якого формується внаслідок емісії та продажу акцій.

Валютний банк - банк, якому надано право купівлі та продажу іноземної валюти.

Депозитний банк - поширений вид банків, які здійснюють операції в основному за рахунок залучених депозитів.

Інвестиційний банк - спеціалізована кредитна установа, яка залучає довготермінові кредити $і$ надає їх у розпорядження позичальникам (підприємствам і державі) шляхом випуску облігацій та інших видів боргових зобов'язань.

Іпотечний банк - банк, який надає довготермінові кредити під заставу нерухомості.

Квазідержавний банк - недержавний, приватний банк, що його контролює держава.

Національні банки - центральні банки країн або комерційні банки (США), діяльність яких регулюється державою.

Ощадний банк - кредитна установа, основна функція якої залучати грошові заощадження та тимчасово вільні кошти населення» [2, с. 60].

Лексема «маркетинг» тлумачиться не як «здійснювана крупними капіталістичними компаніями система заходів щодо вивчення ринку», а «комплексний підхід до управління виробництва і реалізацією продукції». 
Аналогічні зміни відбулися 3 визначенням значення слова «менеджмент» - «управлінням виробництвом, що вживалося в США і ін. капкраїнах», а в сучасному словнику мовиться, що «менеджмент -

1) Сукупність принципів, методів, засобів $і$ форм управління виробництвом з метою підвищення його ефективності, збільшення прибутків.

Кредитний менеджмент - процес управління дебіторською заборгованістю підприємства, метою якого $\epsilon$ забезпечення своєчасної інкасації боргу.

Фінансовий менеджмент - система, принципів, методів і форм організації грошових відносин.

2) Керівництво підприємства, фірми; керівний орган» [2, с. 658].

Подібним же чином знімається негативна конотація в тлумаченні лексеми «рента - дохід з капіталу, землі або майна, що його власники одержують регулярно, не займаючись підприємницькою діяльністю.

Абсолютна рента - форма земельної ренти, одержувана землевласниками незалежно від родючості і місця розташування земельних ділянок.

Довічна рента - умовна рента, при якій платежі припиняються у разі смерті певної особи (або осіб), зазвичай ануїтента.

Натуральна рента - рентна плата у вигляді частини врожаю орендаря, що передається землевласнику» [2, с. 1213].

Можна говорити навіть про появу в тлумаченні ряду подібних лексем позитивної конотації.

У даний час налічується понад тисячі фінансово-економічних понять, які увійшли до ужитку останніми роками і були вміщені до словника.

Сучасна економічна термінологія з погляду джерел формування розподіляється на цілий ряд груп.

Можна виділити значний пласт лексичних одиниць, що є деяким постійним фондом економічної термінології (незалежно від типу економіки).

Дані слова виражають базові загальноекономічні поняття і категорії, наприклад: виробництво, споживання, виробничі стосунки, виробничі сили, капітал, базис, надбудова, попит, пропозиція, товар, товарообіг, вартість, ціна, гроші, додатковий продукт, бюджет, національний дохід, експорт, імпорт і ін.

Численну групу, яка на сьогоднішній день $є$ відкритим рядом, складають іншомовні запозичення (переважно з англійської мови, 
американізми). Вони відображають перш за все тенденцію до інтернаціоналізації економічної термінології, що істотно стимулюється наявністю прямих і безпосередніх контактів 3 іноземними партнерами.

Семантичні перетворення в лексиці, разом з номінацією нових реалій, сприяють розширенню і збагаченню словарного складу.

Набуття словом нового значення може призвести до народження нового слова, підсиливши тим самим мовну омонімію. Серед семантичних процесів виділяються три основних: розширення значення; звуження значення; переосмислення.

Одним із найбільш живих і соціально значущих процесів, що відбуваються в сучасній українській мові, - процес активізації вживання іншомовних слів. Треба говорити про активізацію вживання цих слів, а не тільки про нові запозичення, оскільки разом із появою неологізмів спостерігається розширення сфер використання економічної термінології.

Умовою запозичення ми також будемо вважати двомовність, тобто результат територіального контакту двох народів. Сюди відносяться також такі види мовної діяльності, як читання, переклад, коментування іноземної преси, участь в міжнародних конференціях, конгресах.

Міжнародні відносини із західним світом зумовили запозичення численних фінансових і комерційних термінів: бартер, ваучер, дилер, дистриб'ютор, інвестор, кліринг, лізинг, ф'ючерсні кредити .

Це запозичення відбулося завдяки орієнтації на західну економічну i банківську систему i залученню українських фінансистів до інтернаціональної термінології. А зважаючи на гостру суспільну актуальність самі терміни виходять за межі професійного слововживання і широко використовуються у пресі, на радіо і телебаченні.

Слово «спонсор», що так з'явилося в середині 80-х років, влилося в ряд за походженням найменувань, що мають схоже значення: меценат - імпресаріо - антрепренер - продюсер. Порівняймо ці значення:

«Спонсор: 1) Поручитель, гарант (напр., гарант позики). 2) Особа чи організація, які матеріально підтримують будь-яку діяльність без одержання від неї прибутку з метою популяризації винятково свого імені (назви), торгової марки. Спонсор телепередачі. // Замовник, організатор, улаштовувач; підрядчик. // Замовник 
реклами, рекламодавець. 3) Той, хто надає кому-небудь допомогу (матеріальну, грошову і т. ін.» [2, с. 1374].

«меценат - багатий покровитель наук і мистецтв, а також їх представників» [2, с. 665].

«Антрепренер - підприємець, який організовує культурновидовищні заходи. // Театральний підприємець; власник, орендатор, утримувач театру, цирку і т. ін.» [2, с. 35].

«Продюсер: 1) Довірена особа кінокомпанії, що здійснює ідейнохудожній та організаційно-фінансовий контроль над постановкою фільму; особа, яка організує, фінансує постановку фільму, вистави і т. ін. 2) Адміністративно-фінансовий організатор діяльності зі здійснення якого-небудь комерційного проекту (різних шоу, концертів, телепрограм, запису альбомів, дисків, відеокліпів і т. ін.)» [2, с. 1152].

Отже, «спонсором» спочатку позначали особу або організацію, які подають фінансову підтримку творчої діяльності артистів, музикантів, художників, потім об'єкт спонсорської діяльності почав розумітися ширше, але компонент «подає фінансову підтримку» зберігся.

Проте на цій хвилі задоволення потреб мови з'явилося багато словесного непотребу, що засмічує мову. Іноземне слово стало престижним. У такому разі вибірковість у застосуванні іншомовної лексики починає втрачатися. Перемагає загальний настрій, мода. Ось деякі лексичні паралелі, що свідчать про відсутність необхідності в запозиченні, оскільки існують лексичні еквіваленти: конверсія (істотне перетворення, зміна умов, заміна одних об'єктів виробництва іншими або одних фінансових інструментів на інші) - перетворення;

консенсус (відсутність у сторін, що домовляються, заперечень проти пропозицій, висунутих під час переговорів) - згода;

реклама - пабліситі (реклама, рекламування, пропаганда; популярність, відомість).

Про надмірну тягу до «чужого» слова свідчить сучасна тенденція до використання замість українського слова іншомовного.

Звичайний магазин змінив назви: супермаркет, міні-маркет, активно представлено назву «бутик», яке в українському вживанні «підвищилося в ранзі» на позначення модного, елітного салонумагазина, де пропонуються дорогі товари: «Бутик: 1) Невеликий магазин, де продаються модний фірмовий одяг і різні аксесуари. 2) Невелика вузькоспеціалізована брокерська фірма з обмеженим колом клієнтів» [2, с. 104].

При більш диференційованому підході до визначення причин запозичення виділяють наступне: 
- потреба в найменуванні нових явищ, понять: інфляція, бізнес, приватизація;

- необхідність у спеціалізації понять: маркетинг (ринок), менеджмент (управління), аудит (ревізія);

- прагнення до модного, сучаснішого слова. На загальному фоні широкого запозичення «заморське слово» виявляється престижним, що звучить красиво. Наприклад: офіс (контора), аудитор (ревізор), франчайза (угода).

\section{Висновки}

Терміни і термінології $\epsilon$ необхідним інструментарієм формулювання наукових теорій, законів, положень і розглядаються як невід'ємний компонент науки та техніки. Оволодіння термінологією $\epsilon$ основним кроком в оволодінні будь-яким спеціалізованим знанням, оскільки термінологічні одиниці відіграють важливу роль в професійній і науковій комунікації.

У сучасному українському житті явища економіки превалюють над іншими, диктують свої умови, $є$ визначальними в багатьох сферах буття нації і держави. Вони стали (чи стають) стрижнем, навколо якого відбуваються основні зміни й інновації.

Така центричність економічних явищ безумовно й наполегливо вимагає їхнього номінування, до того ж не тільки на рівні загального, а й деталей. Означене підсилюється й значним обсягом нового в економіці, яке необхідно усвідомити.

I, як бачиться, важливими серед них $\epsilon$ висвітлення явищ сталих і явищ, що $є$ виявом зрушень і змін, та особливостей розвитку в контексті загальнотермінологічному. Маємо добрі початки у працях I. Кочан (присвячених динаміці і кодифікації термінів із міжнародними компонентами в сучасній українській мові) [10] i Л. Струганець (присвячених динаміці лексичних норм української літературної мови XX століття) [18], це добрі, але все ще тільки початки. Важливість означеного дослідження бачиться й у зв'язку 3 визначенням перспектив розвитку української економічної терміносистеми.

У зв'язку 3 означеним було вирішено завдання нашого дослідження:

- установлення основних чинників, що сприяють змінам у термінології;

- з'ясування рівнів, на яких відбуваються найпомітніші зміни (семантичні, словотвірні, стилістичні, морфологічні тощо); 
- основні шляхи становлення економічної термінології і принатурення її до наявних систем тощо.

У цьому важливими можуть стати методи мовознавчого дослідження як загально застосовувані (описовий, порівняльний, експериментальний), так і специфічні (метод моделей, метод опозицій, метод дистрибуцій).

Аналіз досліджуваного матеріалу показує, що основним способом поповнення економічної термінології $\epsilon$ семантична і словотворча деривації.

Морфологічний спосіб термінотворення позначається неоднаковою продуктивністю, більш продуктивним $є$ суфіксальний і префіксально-суфіксальний способи творення економічних термінів.

Економічній термінології властиві значущі процеси, що відбуваються в сучасній українській мові, а саме: процес активізації вживання іншомовних слів та запозичень, коли терміни набувають нового значення, розширення, звуження чи переосмислення значення.

Необхідність подальшого детального вивчення економічної термінології української мови зумовлено, з одного боку, активним розвитком української термінології, що в повному обсязі ще не досліджено, а з іншого - потребою багатоаспектного вивчення всіх складників системи української мови, виявлення особливостей їх структури і функціонування, закономірностей їх взаємозв’язків.

\section{Список використаних джерел:}

1. Безпояско О.К., Городецька К. П. Морфеміка української мови. Київ, 1987. 211 с.

2. Великий тлумачний словник сучасної української мови (з дод., допов. на CD) / Уклад. і голов. ред. В. Т. Бусел. Київ : Ірпінь : ВТФ «Перун», 2009. 1736 с.: іл. - ISBN 966-569-013-2.

3. Винокур Г.О. О некоторых явлениях словообразования в русской технической терминологии. Труды Моск. ин-та ист., фил. и лит-ры : сб. статей по языкознанию. Москва, 1939. Т. І. С. 12 - 14.

4. Гринев С. В. Терминоведение : итоги и перспективы. Терминоведение. Москва : Московский лицей, 1993. Вып. 3. С. 5 - 13.

5. Даниленко В.П. Русская терминология: опыт лингвистического описания. Москва : Наука, 1977. 247 с.

6. Даниленко В.П. О терминологическом словообразовании. Вопросы языкознания. 1973. № 4. С. 76 - 85. 
7. Данилов Г.Л. Язык общественного класса (по данным говора села Белки Полтавского округа). Ученые записки ин-та языка и литры (лингвистическая секция). Москва, 1928. Т. 3. С. 163 - 194.

8. Ділова і народно-розмовна мова XVIII ст. (матеріали сотенних канцелярій і ратуш Лівобережної України) / Підготував до видання В. А. Передрієнко. Київ : Наукова думка, 1976. 416 с.

9. Доманицький В. Словарик. Пояснення чужих та не дуже зрозумілих слів. Київ : Друк. Борисова, 1906. 128 с.

10. Кочан I.М. Динаміка і кодифікація термінів з міжнародними компонентами в сучасній українській мові. Львів : Вид-ий центр ЛНУ ім. Івана Франка, 2004. 520 с.

11. Лотте Д. С. Основы построения научно-технической терминологии. Москва : Изд-во АН СССР, 1961. 158 с.

12. Оглоблин О. Проблема української економіки в науковій і громадській думці XIX - XX в. Червоний шлях. 1928. № 9 - 10. С. 165 - 179.

13. Панько T.I. Від терміна до системи. Львів : Вища школа. Вид-во при Львівському університеті, 1979. 146 с.

14. Панько T.I., Кочан I.M., Мацюк Г.П.Українське термінознавство. Львів : Світ, 1994. 216 с.

15. Передрієнко В.А. Формування української літературної мови XVIII ст. на народній основі. Київ : Наукова думка, 1979. 144 с.

16. Скороходько Є.Ф. Про нормалізацію термінології (словотворчі моделі українських науково-технічних термінів). Про культуру мови. Київ : Наукова думка, 1964. С. $261-270$.

17. Словник староукраїнської мови : XIV - XV ст. : у 2-х томах. Київ. : Наукова думка, 1978.

18. Струганець Л. Динамічні процеси в лексико-семантичній системі української літературної мови XX ст. Тернопіль, 2002. 352 с. 